\title{
Internal teacher portal as a tool for optimization of the educational process of the general school
}

\author{
Osadchyi V., Kruglik V., Prokofiev I., Serdiuk I. , Kupchak Y., Burceva Y. \\ Bogdan Khmelnitsky Melitopol State Pedagogical University, Melitopol, Ukraine.
}

Received: 11.02.2019 Accepted: 10.03 .2019

\begin{abstract}
Using the internal portal of the teacher is an expedient method of optimizing the educational process of the general school. At the initial stage of work, the features of development and existing software tools for the development of software using the technology of the augmented reality have been explored. At the development stage, using the tool kit Vuforia, the ARKit software library and the Unity 3D frameworks, a structure and model of the tool for mocking the objects on the map of the city of Melitopol was developed. At the last stage of the work, the database of the software was filled with a set of places markers in the city of Melitopol. On the basis of the analysis of scientific, special literature and network sources, the concept of the portal is considered, which is considered as a web site intended to provide integrated information; a multilevel combination of resources and services that include a link to other sites whose topics correspond to the visitor's insights to the portal. Horizontal (custom), vertical, corporate and industrial portals are highlighted. It was determined that most portals of educational orientation belong to vertical-portals. The paper defines the educational port-lu as a systemic multi-level association of various informational and educational resources and program complexes, which operate on the basis of a single database and unified standards of information exchange, designed for a certain audience of users and intended for analysis, processing, delivery of educational information and the provision of access to a variety of personalized gray whales using any device connected to the Internet. On the basis of the analysis of the Ukrainian segment Inter-No, the education of portals by subject was classified into the following groups: informational content of portals assigned, education news; educational-methodical - the content of the portals is aimed at helping teachers in preparing for the on-school educational process in school; Subjects - the content of the portals is aimed at helping teachers in preparing for the lessons; service - portals provide services for organizing and maintaining the educational process of the school; qualification improvement - portals that enable teachers to improve their professional competence; regional. Based on the experience of using portal systems in the learning process, it has been determined that such portals as "Class Rating" and "Diary" are widely used in Ukraine. In the work, methodical recommendations for teachers on using the portal in the general education school were developed. They include a description of work with the main sections of the portal "Live tape", "Task", "Calendar". The originality of the study is to explore the peculiarities of the use of portal technologies in the educational process in the use of the internal portal of the teacher to optimize the educational process of the general school and to develop methodological recommendations for using the online portal of the teacher to optimize the educational process of the general school. An analysis of the feasibility of using an online portal in the educational process of a secondary school and developing methodological guidelines for using the portal for the optimization of the educational process. References 20 , figure 9.
\end{abstract}

Keywords: portal technology, web-portal, educational portal, quality of education, educational process.

\section{Внутрішній портал вчителя як засіб оптимізації навчального процесу загальноосвітньої школи}

\author{
Осадчий В. В., Круглик В. С., Прокоф'єв Є. Г., Сердюк І. М., Купчак Є. О., Бурцева Є. 0. \\ Мелітопольський державний педагогічний університет імені Богдана Хмельницького, Мелітополь, Україна.
}

Анотація. У статті проаналізовано та відображено теоретичне обґрунтування доцільності використання внутрішнього порталу вчителя для оптимізації навчального процесу загальноосвітньої школи. Авторами було

\footnotetext{
Corresponding Author: Serdiuk Iryna Mikolaevna. Tel. +38(097) 718 2371. E-mail: serdiuk_iryna@mdpu.org.ua Bogdan Khmelnitsky Melitopol State Pedagogical University, Str. Getmanska, 20, Melitopol, Zaporozhye region, Ukraine, 72312.

Відповідальний автор: Сердюк Ірина Миколаївна. Тел. +38(097) 718 2371. E-mail: serdiuk_iryna@mdpu.org.ua Мелітопольський державний педагогічний університет імені Богдана Хмельницького, вул. Гетьманська, 20, м. Мелітополь Запорізької обл., Україна, 72300.
} 
проведено аналіз сучасного стану наукових досліджень розробки та використання онлайн-порталів у сфері оптимізації навчального процесу та освітнього процесу в цілому. На основі проведеного аналізу вітчизняних та зарубіжних дослідників, авторами було визначено основні задачі та особливості онлайн-порталів, їх склад, типи та проблеми, які інтернет-портали вирішують. Було проведено аналіз існуючих онлайн-порталів, які використовуються у вирішенні завдань підвищення якості освітнього процесу, налагодження взаємозв'язку між структурними підрозділами освітнього закладу та створення загального педагогічного простору для всіх учасників освітнього процесу. У рамках дослідження авторами було розроблено внутрішній інтернет-портал вчителя та, на основі отриманого досвіду, розроблено та відображено методичні рекомендації що до використання внутрішнього порталу вчителя. Автори зазначають, що проведений аналіз дозволив з'ясувати, що в вітчизняному сегменті Інтернет-мережі $€$ інфрормаційні ресурси, які загальноосвітні школи можуть застосовувати для оптимізації навчального процесу, такі портали було класифіковано сервісні, проте ці сервіси не мають такий функціонал, як можливість здійснювати управління персоналом школи. Автори зазначають, що проведений внутрішній аналіз існуючих інструментів для розробки інтернет-порталів показав, що при розробці освітніх інтернет-порталів для оптимізації навчального процесу загальноосвітньої школи доцільно використовувати хмарний сервіс «Бітрікс24», як засіб для розробки внутрішнього порталу вчителя для оптимізації навчального процесу загальноосвітньої школи. Результати розробки внутрішнього порталу уявляють собою відображення основних блоків готового внутрішнього порталу та методичні рекомендації по використанню внутрішнього порталу вчителя, як засобу оптимізації навчального процесу загальноосвітньої школи.

Ключові слова: портальна технологія, web-портал, освітній портал, якість освіти, навчальний процес.

\title{
Внутренний портал учителя как средство оптимизации учебного процесса общеобразовательной школы
}

\author{
Осадчий В. В., Круглик В. С., Прокофьев Е. Г., Сердюк И. Н., Купчак Е. А., Бурцева Е. А.
}

Мелитопольский государственный педагогический университет имени Богдана Хмельницького, Мелитополь, Украина.

\begin{abstract}
Аннотация. В статье проанализировано и отражено теоретическое обоснование целесообразности использования внутреннего портала учителя для оптимизации учебного процесса общеобразовательной школы. Авторами был проведен анализ современного состояния научных исследований разработки и использования онлайн-порталов в сфере оптимизации учебного процесса и образовательного процесса в целом. На основе проведенного анализа отечественных и зарубежных исследователей, авторами были определены основные задачи и особенности онлайн-порталов, их состав, типы и проблемы, которые интернет-порталы решают. Был проведен анализ существующих онлайн-порталов, которые используются в решении задач повышения качества образовательного процесса, налаживания взаимосвязи между структурными подразделениями образовательного учреждения и создание общего педагогического пространства для всех участников образовательного процесса. В рамках исследования авторами был разработан внутренний интернет-портал учителя и на основе полученного опыта, разработаны и отражены методические рекомендации по использованию внутреннего портала учителя. Авторы утверждают, что проведенный анализ позволил выяснить, что в отечественном сегменте Интернет-сети имеются информационные ресурсы, которые общеобразовательные школы могут применять для оптимизации учебного процесса, такие порталы были классифицированы как сервисные, однако эти сервисы не имеют в своем функционале такого блока, как возможность осуществлять управление персоналом школы. Авторы отмечают, что проведенный внутренний анализ существующих инструментов для разработки интернетпорталов показал, что при разработке образовательных интернет-порталов для оптимизации учебного процесса общеобразовательной школы целесообразно использовать облачный сервис «Битрикс24», как средство для разработки внутреннего портала учителя для оптимизации учебного процесса общеобразовательной школы. Результаты разработки внутреннего портала представляют собой отражение основных блоков готового внутреннего портала и методические рекомендации по использованию внутреннего портала учителя, как средства оптимизации учебного процесса общеобразовательной школы.

Ключевые слова: портальная технология, web-портал, образовательный портал, качество образования, учебный процесс.
\end{abstract}

\section{Bcmyn}

На сучасному етапі розвитку України одним з головних економічних завдань $є$ підвищення ефективності освіти, зокрема навчального процесу у загальноосвітніх школах на основі інформаційнокомп'ютерних засобів. У зв'язку з цим важливого значення набувають новітні технології та їх науково обґрунтоване впровадження у навчальний процес загальноосвітньої школи. 
Актуальність питання визначається тим, що інфрормаційно-комп'ютерні засоби здійснюють вплив на покращення результатів навчальної діяльності, допомагають оптимізувати навчальний та адміністративний процеси у загальноосвітній школі, беручи на себе рутинні завдання, також простежується залежність відповідно сфрормованого інформаційно-комп'ютерного навчального середовища з результатами навчання і виховання школярів.

У сучасній освіті одним з пріоритетних напрямів її модернізації $є$ впровадження інформаційнокомп'ютерних технологій у навчальний процес. Проте серед різноманіття інформаційних технологій керівництву шкіл важко обрати оптимальний варіант інформаційно-комп'ютерного середовища для роботи школи. Ця проблема потребує аналізу потреб школи та пошуку відповідного інформаційнокомп'ютерного засобу для організації навчального процесу.

Проблеми інформатизації освітнього процесу розглядали В.П. Вембер [1], О.М. Гончарова [2], В.Г. Кремень [3], В.В. Осадчий [4], Ю.С. Рамський [5]. Особливу увагу теоретичним і практичним питанням формування єдиного освітнього інформаційного простору приділяв В.Ю. Биков [6]. Питання розробки програмних засобів для освітніх цілей висвітлювали Ю.М. Ільїна [7], М.М. Козяр [8]. Оптимізації навчального процесу в освіті присвячено праці Л.М. Забродської [9], Т.А. Вакалюк і М.К. Шевельової [10], І.А. Вербовського [11].

Зростаюча потреба в створенні уніфікованого порталу для учителів, основними цілями якого являються сприяння налагодженню діалогу між школою і сім'єю, школою і суспільством, батьками і дітьми, вчителями і учнями; зміцнення зв'язків між учасниками шкільної спільноти: вчителями, школярами, випускниками, батьками, через інформування про шкільне життя, через систему зворотного зв'язку; допомога вчителям у оптимізації навчального процесу загальноосвітньої школи визначає актуальність даного дослідження.

Мета роботи: проаналізувати використання портальних технологій як засобу оптимізації навчального процесу загальноосвітньої школи та описати застосування внутрішнього порталу вчителя.

\section{II Матеріал і методи дослідження}

Для керування навчальним процесом школи на базі інформаційно-комп'ютерних технологій тривалий час створювалися автоматизовані системи управління. На сучасному етапі розвитку інформатизації адміністративних процесів в навчальних закладах існує широкий ряд програмних продуктів. Наприклад, корпорація КВАЗАР-Мікро, відомий Інтернет-провайдер УКРСАТ та деякі фірмивиробники, які працюють в інтересах сфери освіти, з 2001 року, розпочали реалізацію проекту «Учбовий комп'ютерний комплекс» [12, с. 142-143]. Для полегшення виконання однотипних та одноманітних операцій керівника використовували автоматизоване робоче місце.

Г.О. Козлакова у свої дослідженнях наводить склад «універсального автоматизованого робочого місця»: 1) телефон, комп'ютер, система швидкого друку; 2) копіювальна машина, фракс апарат, інтерфейс для підключення комп'ютера до локальної мережі; 3) вхід до спеціалізованих баз даних, довідкові системи типу Телетекс, Відеотекси [13].

П.А. Гевал зауважує, що «розв'язуючи завдання управлінської діяльності за допомогою інформаційних технологій, можна уникнути таких протиріч в роботі управлінця, як: а) необхідність прийняття чисельних оперативних рішень, і повільне збирання та опрацювання інформації з проблем, що потребують розв'язування; б) необхідність у компетентності управлінців та велика динаміка інформаційно-правового забезпечення; в) великий обсяг обчислювальної роботи для опрацювання статистичної інформації та відсутність її автоматизації; г) виключення можливостей визначення неперспективних шляхів розвитку колективу та неможливість моделювання майбутніх процесів 3 використанням традиційних підходів». Впровадження у 2000 році нових інфрормаційних технологій в управлінській діяльності навчально-виховного комплексу НВК №2 м. Хмельницького відбувалося за такими напрямками: 1) науково-методичний - створення бази даних стосовно педагогічних працівників та учнів навчального закладу, інформаційного забезпечення навчально-методичного комплексу; 2) освітній - для опрацювання інформації про якість навчання, формування знань, умінь та навичок учнів, рівень розвитку дітей дошкільного віку; 3) психолого-педагогічний - для тестування учнів та вчителів; 4) бухгалтерський - для фрінансової звітності, нарахування заробітної плати, ведення фрінансових документів. На основі наявного досвіду П.А. Гевал виділяє три етапи впровадження нових 
інформаційних технологій в управління навчальним закладом: 1) введення в управлінську діяльність нового аспекту інтелектуальної праці адміністратора, як засобу особистої зайнятості, для чого розробляються і впроваджуються інформаційні проекти підготовки працівників закладу до роботи 3 персональним комп'ютером, проекти для збирання, опрацювання та збереження інформації; 2) створення баз даних, необхідних керівникові навчального закладу для одержання, передавання, аналізу та збереження інформації: бази даних про технічний та педагогічний персонал закладу, про учнів (вихованців, студентів), телефонів тощо; 3) створення баз даних "Бібліотека", "Господарська діяльність", а також впровадження Інтернет у навчальний процес [14, с. 207-209].

Нині у зв'язку із постійним збільшенням за останні десятиліття об'ємів інформації проблеми обміну інформаційними ресурсами постали перед людством дуже гостро. Поява і розповсюдження комп'ютерної техніки, яка стала потужним засобом накопичення і обробки інформації, не вирішили питання про швидку і ефективну передачу даних на значній відстані. Інформаційний ресурс людства зростав і зростає у геометричній прогресії, тому важливим внеском у вирішення проблеми передачі інформації стали комп'ютерні та інші мережі передачі даних. У комп'ютерних мережах у вузлах мережної структури знаходяться комп'ютери, які поєднані між собою за допомогою дротових чи волоконно-оптичних ліній або бездротовими засобами зв'язку.

Як зазначає О.М. Коваль, використання мережних технологій в освіті реалізується на практиці в трьох основних варіантах:

1. Інформаційно-пошукова робота викладачів і учнів у глобальній мережі. При цьому варіанті пошукова робота педагогів і учнів протікає практично незалежно один від одного, кожен з них керується власними цілями.

2. Власне дистанційне навчання. У цьому випадку учень веде дистанційний діалог з певним викладачем, послідовно і методично засвоюючи певний навчальний курс, відповідаючи на питання і виконуючи завдання, що надсилаються по мережі. Викладач контролює й оцінює навчальну діяльність підопічного, надаючи йому необхідну педагогічну допомогу і моральну підтримку.

3. Організація соціальної і творчої діяльності молоді з використанням інформаційно-комп'ютерних технологій. Мається на увазі організація в мережі олімпіад, вікторин, диспутів, випуск електронних газет і журналів, проведення відеоконфреренцій, створення навколо інформаційно-освітнього центру навчального закладу молодіжного активу [15, с. 87-88].

С.О. Сисоєва та В.В. Осадчий до цього переліку додають таке [16]:

4. Віддалене чи безпосереднє керування навчальним закладом та іншими ланками системи освіти за допомогою автоматизованих робочих місць (APM), інформаційно-аналітичних систем (IAC) управління, систем передачі даних тощо;

5. Спілкування на відстані суб'єктів освітнього процесу за допомогою чатів, форумів, телеконференцій, ICQ.

Однією з провідних мережних технологій є портальні системи (портали).

Як зазначає. В.В. Осадчий [4, с. 129], поняття порталу слід розпочати з поняття Web-сторінки. Web-cторінка являє собою гіпертекстовий документ, що зберігається як текстовий файл (звичайно 3 розширенням .htm чи .html). Гіпертекстовий документ містить посилання на інші документи, які з ним пов'язані, забезпечуючи можливість швидкого їх перегляду за цими посиланнями. Концепція гіпертексту лежить в основі системи WWW (World Wide Web - всесвітнє павутиння), яка на сьогодні є домінуючою системою забезпечення доступу до інформації світової мережі, що складається з взаємопов'язаних електронних документів, що зберігаються на Web-серверах.

B Інтернеті терміном «портал» вперше стали називати сайти такі як AOL, Excite, Yahoo, MSN, Netscape Netcenter, з огляду на те, що саме їх використовували більшість користувачів як відправну точку своєї мандрівки у мережі. Кінцевим етапом еволюції сайтів таких компаній стало створення так званих горизонтальних чи користувацьких порталів. Більшість крупних освітніх порталів можна віднести саме до вертикальних порталів. Останнім часом, у зв'язку із подальшою еволюцією Інтернету і розвитком механізмів використання мережі у корпоративних і комунікативних цілях призвели до того, що на даний момент можна визначити ще два типи порталів: корпоративні портали та індустріальні [17].

Ю.В. Триус, С.В. Бесєдков та В.А. Пустовіт стверджують, що «за своєю суттю портал являє собою Web-сайт, організований як системне багаторівневе об'єднання різних інформаційних ресурсів і 
сервісів, розрахований на певну аудиторію користувачів і призначений для аналізу, обробки, доставки інформації та надання доступу до різних сервісів на основі персоналізації за допомогою будь-якого пристрою, підключеного до Internet» [18, с. 101].

На думку Д. Орштейна, портал - це не просто Web-сторінка з багатьма посиланнями на вузли, що цікавлять споживачів. Насправді це сторінка, яка пропонує користувачу дані як зі структурованих джерел, таких як бази даних, електронні таблиці і додатки планування корпоративних ресурсів, так і 3 неструктурованих джерел, тобто з Web-сторінок, документів та електронної пошти. Портал включає в себе механізм пошуку і велику кількість розподілених за категоріями і класифікованих списків множини сторінок, розміщеної в intranet інформації. Портал інтегрує внутрішні додатки, такі як додатки електронної пошти, доступу до бази даних і управління документами, із зовнішніми додатками, наприклад, службами новин і споживчими Web-вузлами. Це Web-iнтерфейс, який дає користувачу можливість звертатися до всіх цих додатків з екрана свого персонального комп'ютера. У обов'язки порталу входить доставка на настільну систему важливої інформації як ззовні, так і зсередини. Він також відфільтровує велику частину сторонньої інформації, а саме тисячі сторінок intranet, призначених для інших користувачів, або ж сторонні повідомлення електронної пошти, адресовані різним користувачам [19, с. 34].

В.М. Соловйов, О.А. Сердюк та Ю.В. Триус називають портал інформаційним середовищем, яке «створюється для підтримки прийняття оперативних рішень у певній галузі діяльності людини та їх всебічного аналізу» [20, с. 226]. В.І. Береговий, А.Д. Іванніков, А.М. Тихонов вважають, що портали $€$ сучасним інструментом, орієнтованим на вирішення проблем розміщення (інформації та сервісів у мережних середовищах), навігації (у широкому розумінні) у мережі, забезпечення доступу до ресурсів i взаємодії користувачів, які забезпечують [21]:

1) розміщення інформаційних ресурсів у середовищі порталу (у тому числі метаінформації, оперативної інформації, персональної та корпоративної інформації, важливіших універсальних сервісів);

2) навігацію (на основі широкого спектра пошукових процедур і спеціалізованих засобів);

3) доступ до ресурсів та взаємодію користувачів (на основі Web-технологій, Wap та ін.).

Отже, сучасна інформатика визначає портал (Інтернет-портал) як веб-сайт, призначений для надання інтегрованої інформації; багаторівневе поєднання ресурсів і сервісів, які містять посилання на інші сайти, тематика яких відповідає інтересам відвідувача порталу [22, с. 403].

Освітній портал визначається як комп'ютерна система в телекомунікаційній мережі Інтернет (сукупність серверів або мультисервісний сервер), налаштована на оперативний доступ до інформаційних ресурсів навчального призначення, на надання освітніх послуг відповідними установами та організаціями; інфотелекомунікаційна форма маркетингового забезпечення відкритої освіти (мережевий маркетинг), що сприяє за допомогою мережевого сервера створення нового комунікаційного простору та інформаційного поля учасників освітнього співтовариства засобами мережі Інтернет; перспективний комерційний напрямок використання мережі Інтернет в формі мережевого дистанційного навчання, коли отримання освіти відбувається в місці, відмінному від місця знаходження навчального закладу або організації; один із засобів входження в єдиний міжнародний інформаційний освітній простір [23, с. 205].

Г.Ф. Дрючатий, А.Е. Заварихін, В.А. Красильникова освітній портал визначають як програмнотехнічний комплекс, який акумулює в різноманітних формах і обсягах територіально розподілені відомості по науково-методичних інформаційних ресурсах, сучасні технології навчання, державних освітніх стандартах і будь-який інший інформації, яка підтримує індивідуальний рівень освіти і інтересу до його підвищення [24].

В.В. Осадчий під терміном «освітній портал» розуміє системне багаторівневе об'єднання різних інформаційно-освітніх ресурсів та програмних комплексів, що працюють на основі єдиної бази даних і єдиних стандартів обміну інформацією, розраховане на певну аудиторію користувачів і призначене для аналізу, обробки, доставки освітньої інформації та надання доступу до різних сервісів на основі персоналізації за допомогою будь-якого пристрою, підключеного до Інтернет [4, с. 136].

Освітній портал вирішує, як правило, такі завдання: освітня діяльність; вдосконалення засобів освітньої навігації в мережі Інтернет в цільовому (освітньому) напрямку; просвітницька діяльність; 
надання інформації і засобів спілкування для викладачів (учителів) і фахівців (професіоналів); поліпшення зв'язків між існуючими ресурсами, кооперація розробників курсів дистанційного навчання та освітніх установ; створення умов для дотримання авторських прав, захисту інтелектуальної власності; оголошення тематичних конкурсів (на кращий мережевий курс, освітню технологію, освітню послугу тощо) і на заміщень вакансій; розміщення рейтингів навчальних закладів, спеціальностей, курсів, викладачів (учителів); можливість обміну інформацією; сервісна служба (чат, науково-практичні телеконференції, доставка інформації обраної тематики, служба поштової розсилки, засоби персоніфікації тощо). Таким чином, освітній портал забезпечує реалізацію освітніх послуг різних спеціалізованих (освітніх) закладів, а також надає широкий набір різноманітних послуг фахівцям освітньої сфрери, науковцям і учням [23, с. 206].

У системі освітніх вертикальних порталів розрізняють профрільні та спеціалізовані портали загального призначення. Профрільні портали обслуговують сфрери знань і, як правило, формуються по ряду суміжних дисциплін [21]. Профільний освітній портал - це WWW-сайт (чи група сайтів) в українському сегменті Інтернет, на якому у систематизованій формі сконцентровані відомості про мережні ресурси по одній з освітніх дисциплін, звертання до яких може бути корисним з метою удосконалення наявних знань чи отримання нових.

Спеціалізовані портали орієнтуються на виконання певних функцій (наприклад, галузевий новинний портал чи галузевий портал для тестування). Також виділяють регіональні освітні портали, які $€$ горизонтальними і об'єднують ресурси нижчих рівнів - портали і сайти вузів, шкіл та інших організацій, і портали-супутники, пов'язані з освітою і створювані у рамках крупних самостійних комерційних чи некомерційних проектів. Вони логічно пов'язуються із системою і можуть бути присутніми на будь-якому рівні. Ще одна категорія портальних конструкцій - це різного роду персональні портали - портики. За бажанням користувача може створюватися локальний портал, розташований на персональному обладнанні користувача [21].

А.В. Андрєєва, Є.Н. Мажар та Н.А. Максимова виділяють такі основні принципи створення і підтримки роботи освітнього порталу [25]:

1. Модульність і відкритість програмного комплексу, що дозволить вести додатки підсистем й оперативно оновлювати інформацію.

2. Вільний доступ до інформації для користувачів порталу.

3. Залучення найбільш відомих фрахівців як авторів та експертів матеріалів, представлених на сторінках порталу.

4. Створення апаратно-програмного комплексу, який дозволить моделювати індивідуальне середовище і траєкторію навчання кожної дитини.

Система освітніх порталів характеризується рядом особливостей [26, с. 29], таких, як:

- велика різноманітність змісту та форм подання інформації;

- великі обсяги освітньої інформації;

- висока швидкість оновлення і поповнення інформації;

- велика територіально-галузева розподіленість інформаційних ресурсів;

- велика кількість і різноманітність груп користувачів.

Характеристиками освітнього порталу є [27, с. 346]:

- підібраний і структурований контент для цілей навчання;

- доступ і відображення інформації з множинних гетерогенних джерел даних (реляційні та багатовимірні бази даних, системи управління документами, системи електронної пошти, Web-сервери, новинні канали та різні фрайлові системи або сервери, на яких зберігаються гіпертекст, аудіо-, відеоінформація або образи);

- персоніфікація для конкретного користувача;

- здатність організації клієнтського місця;

- розподіл ресурсів - поділ деяких можливостей порталу на рівні, доступні різним категоріям користувачів;

- відстеження виконання робіт конкретною людиною або спільнотою людей;

- виявлення (локалізація) людей і інформації (експертів, спільнот і контенту, пов'язаного 3 певною тематикою). 
Визначають такі базові сервіси і служби освітніх порталів [17]: сервіси пошуку інформації і навігації по ресурсам порталу; інформаційні сервіси; сервіси інтерактивного спілкування користувачів порталу; сервіси персоніфікації індивідуального і корпоративного порталів користувача; сервіси моніторингу і статистики; засоби (служби) експорту й імпорту інформаційних і функціональних ресурсів порталу; служба аутентифікації й авторизації доступу до змісту порталу.

Освітні портали, як ми бачимо на прикладі Освітнього порталу (http://osvita.org.ua), Освіта в Україні (http://www.parta.com.ua), Шкільний портал «Острів знань» (http://ostriv.in.ua) та ін., містять інформацію про вищі навчальні заклади країни, освіту в країні та за кордоном, мають каталоги освітніх ресурсів, де розміщені корисні посилання освітньої тематики та форуми, також обговорюються питання вищої, середньої та дистанційної освіти, генеруються новини науки та освіти, працює електронна пошта та є реєстрація відвідувачів.

Ґрунтуючись на результатах пошуку в системі Google можна констатувати, що за запитом «освітній портал» є 20100000 результатів. На основі аналізу українського сегменту Інтернет ми класифікували освіті портали за тематикою на такі групи:

1) інформаційні - контент порталів присвячено, новинам у сфрері освіти (Освітній портал http://osvita.org.ua, Педрада - https://www.pedrada.com.ua);

2) навчально-методичні - контент порталів спрямований на допомогу учителям у підготовці до ведення навчально-виховного процесу у школі (Шкільний портал «Острів знань» - http://ostriv.in.ua);

3) предметні - контент порталів спрямований на допомогу учителям у підготовці до проведення уроків (Портал вчителів початкових класів "Урок" -http://www.yrok.net.ua, Портал учителів біології Вінниччини - http://biovin.at.ua, Української платформи для вчителів іноземних мов» - https://nusenglish.com.ua);

4) сервісні - портали надають сервіси для організації і ведення навчального процесу школи (Класна оцінка - http://klasnaocinka.com.ua, Щоденник - shodennik.ua); у тому числі портали для організації дистанційного навчання (Gnomio - https://www.gnomio.com);

5) підвищення кваліфікації - портали, які надають можливість учителям удосконалювати свої профресійній компетентності (Intel囚 «Навчання для майбутнього» - http://iteach.com.ua, Educational Era https://www.ed-era.com);

6) регіональні - освітні портали певного регіону (Освітній портал Львівщини http://osvitportal.Iviv.ua, Освітній портал Дніпропетровщини - http://dnepredu.com, Освіта Харкова, http://www.kharkivosvita.net.ua).

Дамо опис найбільш популярних освітніх порталів:

«Освітній портал» (www.osvita.org.ua), який було засновано в середині 2002 р., в онлайні проект з'явився в січні 2003 р., спочатку мав на меті якісне інформування громадян щодо вищої освіти в Україні. Так, першим розділом проекту був електронний довідник «ВНЗ України», згодом з'явилися «Новини освіти та науки», «Каталог освітніх сайтів», «Календар освітніх подій» та багато інших цікавих розділів. Мета на сьогодні - розширити створений простір для спілкування освітян онлайн, наповнювати його свіжою та актуальною інформацією галузі. Найбільше портал відвідує молодь, що користується новітніми технологіями: школярі, абітурієнти, студенти. Також проект цікавий молодим науковцям, викладачам, керівникам ВН3 та батькам абітурієнтів.

Всеукраїнський освітній портал «Острів знань» має на меті створення потужного соціальноосвітнього простору, який об'єднає між собою учнів, педагогів та батьків, і призначається не лише для обміну інформацією, а й для обговорення питань і проблем, що виникають в галузі освіти, реального їх розв'язання наявними засобами й ресурсами. Основні цілі Всеукраїнського освітнього порталу «Острова знань» для вчителів:

- надання підтримки професійної діяльності вчителя;

- надання можливості самореалізації та самоствердження через спільну практичну діяльність;

- створення та підтримка нових освітніх ініціатив;

- створення єдиного інформаційного педагогічного ресурсу;

- організація практичної діяльності та взаємодії вчителів у мережі;

- підготовка єдиної бази текстових, аудіо та відеоматеріалів для віддаленого навчання й екстернату; 
- розвиток і реалізація творчих здібностей учасників проектів.

Основні цілі Всеукраїнського освітнього порталу «Острова знань» для учнів: надання підтримки учневі в навчальному процесі; надання можливості самореалізації та самоствердження через спільну практичну діяльність; участь у різноманітних проектах та набуття знань в різних предметних галузях; розширення кола спілкування, виховання толерантності, розвиток критичного мислення; отримання доступу до учбових та пізнавальних матеріалів дітям з особливими потребами, дітям що навчаються за кордоном та учням екстернату; розвиток самостійності й відповідальності; робота в одній команді учнів і вчителів. Для загальної аудиторії, у тому числі для батьків, використання Всеукраїнського освітнього порталу «Острова знань» - це можливість безпосередньої участі в навчальному та позанавчальному процесах, в оцінюванні якості освіти, в обговоренні й створенні проектів, які можуть визначати стратегію розвитку освіти загалом.

Основні матеріали «Української платформи для вчителів іноземних мов» (https://nusenglish.com.ua) дають подальшу інформацію для поглибленого вивчення тем з іноземної (англійської) мови. Вивчивши основні матеріали на порталі, вчитель зможе пройти тест і отримати електронне підтвердження про проходження курсу. Додаткові матеріали порталу допоможуть вчителю урізноманітнити уроки та покажуть подальші можливості для професійного розвитку. Як зазначають розробники платформи, з навчальною платформою вчителів чекають: визнання важливості ролі вчителя у навчальному процесі; підвищення професійного рівня та результативності; розуміння того, що дитина має бути центром навчального процесу; найновіші знання і методи викладання; можливість ефективно використовувати мовні прийоми в спілкуванні; можливість зробити уроки цікавішими для дітей і більш продуктивними; нагоду спостерігати, як діти вчаться за знання, а не за оцінки; перспективу сприяти розвитку навичок мислити категоріями XXI сторіччя; можливість заощадити час підготовки навчальних планів завдяки високоякісним ресурсам; отримання професійного задоволення від легкості, з якою діти сприймають вас і ваш стиль навчання; заслужену повагу батьків учнів [2].

Портальна система «Класна Оцінка» (http://klasnaocinka.com.ua) як проект був створений для вирішення ряду проблем, які існують в освіті, зокрема: максимально ефективне використання існуючої матеріально-технічної бази; підвищення соціального статусу працівників освіти; підвищення ефективності системи управління на всіх рівнях; забезпечення рівності в доступі до якісної освіти; підвищення якості освіти та рівня знань і вмінь учнів, використання сучасних методів і методик навчання; оновлення змісту освіти; необхідність максимального збереження досвіду педагогічних кадрів для молодих фахівців, які приходять до навчальних закладів на роботу, можливість професійного росту вчительських кадрів; ефективна система моніторингу і контролю якості освіти; можливість компенсації нестачі якісних навчальних матеріалів і використання передових технологій в освітньому секторі.

Для навчальних закладів портал дозволяє забезпечити:

- інформаційну підтримку навчального процесу;

- підвищення рівня освіти завдяки доступу до кращих педагогічних напрацювань, створенню системи неперервної освіти через організацію єдиного навчально-виховного простору навчальних закладів, створенню комп'ютерно-орієнтованого середовища для навчання дітей, в тому числі і 3 особливими потребами;

- отримання освіти за місцем проживання, використовуючи різні форми, в тому числі дистанційну;

- підтримку навчального процесу для осіб, які потребують підвищення якості середньої освіти для отримання доступу до вищої.

Портал «Класна Оцінка» має такий перелік і можливості основних електронних сервісів:

1. Електронний документообіг.

Широкий набір сервісів (робота з розкладом занять і електронним журналом, електронні щоденники, домашні завдання, оцінки та зауваження, прив'язані до розкладу занять, інформація, новини, спілкування між користувачами тощо). Поурочні планування. Повний моніторинг поточної успішності учнів. Календарне річне планування з системою контролю, повний моніторинг роботи вчителів. Широкий набір вибірок інформації для користувачів. Створення архівів за минулі роки. Конструктор форм запитів. Електронна реєстрація в навчальний заклад. 
2. Система створення електронного контенту та дистанційного навчання. Повнофункціональна система управління дистанційним навчанням (LMS). Створення навчальних матеріалів (електронного контенту): урок, в тому числі створення flash-анімації, для використання на заняттях, різні роботи, глосарій, актуальні питання, файловий архів і медіатека, бібліотека. Flash-конструктор для роботи 3 мультимедійними дошками на заняттях. Широкий набір інструментів для створення тестів (множинний вибір, одиничний вибір, на відповідність) і перевірки засвоєння матеріалу. Вбудована система і сценарії контролю і оцінки знань. Створення різних видів дистанційних курсів (автоматичних, з підтримкою викладачем). Вільний доступ до дистанційних курсів та контенту через зручний web-портал. Налаштування прав доступу до створеного контенту самим автором. Організація спілкування 3 викладачем і між учнями через форум, персональні повідомлення, вбудований сервіс Internetконференції тощо.

3. Конструктор сайтів.

Створення повнофункціонального багатомовного порталу навчального закладу зі зручною інтеграцією всіх сервісів. Проста система управління (CMS) порталом закладу. Система розподілу прав доступу користувачів до редагування окремих розділів порталу закладу. Конструктор новин. Конструктор дизайнів - простий і зручний інструмент для тих, хто хоче створити власний дизайн сайту.

4. «Віртуальний клас».

Дозволяє самостійно проводити Internet-конференції (до 50 користувачів).

5. Конструктор конкурсів.

Дозволяє проводити конкурси, опитування, голосування.

6. Система адресних і групових повідомлень.

Викладачі, учні та батьки школярів можуть обмінюватися між собою адресними особистими повідомленнями. Цей сервіс не може замінити повноцінне спілкування, але зможе доповнити систему комунікацій між учасниками навчально-виховного процесу в навчальному закладі. Також він стане при нагоді для системи дистанційного навчання.

\section{7. Блоги.}

Доступ кожного користувача до своїх блогів дозволяє публікувати статті на шкільному сайті. Крім того, окремі фахівці (лікарі, психологи, методисти, провідні викладачі та ін.) можуть вести свої блоги і публікувати статті по тематиці, яка цікава відвідувачам як сайту навчального закладу, так і Порталу в цілому. Блоги можуть вести також і учні, й їхні батьки.

8. Створення електронних газет і журналів.

На основі блогів можна будувати систему обміну досвідом між відвідувачами сайту; створювати навчально-методичні електронні журнали навчального закладу з різних тематик.

9. Форум.

Невід'ємна складова сучасного web-сайту. Модуль форуму дозволяє обговорювати користувачами навчального закладу окремих тем. Цей модуль також дозволяє створювати постійно діючі конференції, «віртуальні» батьківські збори і багато іншого.

10. Фото- і відео-галереї.

11. Конструктор панорам (3-D).

12. Файлові архіви.

13. Електронна бібліотека.

14. Електронна медіатека та багато іншого.

Навчальні заклади можуть використовувати в своїй роботі як всі сервіси, об'єднуючи в рамках створюваного за допомогою Конструктора сайту, так і окремі модулі Порталу «Класна Оцінка», необхідні закладу в його діяльності. Це робить Портал «Класна Оцінка» застосовним навіть в умовах наявності в навчальних закладів власного сайту (https://nus-english.com.ua).

Портал Educational Era (https://www.ed-era.com) - український освітній проект, що створює повноцінні онлайн-курси та супроводжувальні матеріали для учителів [2]. На портал присутні розділи «Курси», «Бібліотека», «Блог», «ЗНО платформа», а також «Про нас» та «Вакансії». Онлайн-курси на порталі Educational Era складаються з інтерактивних лекцій, конспектів, мають домашні завдання, екзамени та сторінка прогресу. 
Інтерактивні лекції - це набір коротких відео, між якими інтегровано запитання для кращого засвоєння матеріалу та контролю знань. Враховуючи досвід західних освітніх платформ та відгуки фокус-груп, було виведено найкращу для сприйняття тривалість відео - 6-10 хвилин. Також важливим аспектом $€$ те, що режим онлайн дає змогу змінювати фрормати подачі матеріалу в рамках однієї лекції. Таким чином, задається динаміка. До кожної лекції на платформі з'являється супроводжуючий матеріал. Основний вид - конспект. Це не просто набір формул, визначень тощо. Це повноцінний розділ книжки 3 ілюстраціями та докладними поясненнями. По завершенню кожного курсу з них складається підручник, який міг би існувати і незалежно від самого курсу. Окрім проміжних запитань під час лекції, на проекті існує ще два методи контролю успішності та прогресу. Кожного тижня потрібно виконати декілька домашніх завдань. Вони мають так званий deadline - час, до якого їх потрібно зробити. Також в середині та в кінці курсу треба виконати більш фундаментальні роботи - екзамени. Залежно від курсу це може бути тест або проектна робота. Усі контрольні завдання оцінюються відповідно до вагового коефіцієнту. Тобто екзамен більш важливий, ніж домашня робота, домашня робота більш вагома, ніж проміжні запитання в лекції. Усі результати потрапляють на сторінку прогресу, і відбувається фоормування остаточної оцінки. Щоб отримати сертифікат про успішне завершення курсу, ця оцінка має бути більшою за певну межу, яка варіюється залежно від обраного курсу. На проекті $€$ можливість спілкування та обговорення проблемних питань курсу з іншими студентами, викладачами та командою на форумі. До кожного запитання, відеолекції та інших частин існує окрема форумна гілка, що робить спілкування більш комфортним та структурованим. Курси постійно оновлюються в залежності від потреб студентів [28].

Освітній портал Львівщини (http://osvitportal.Iviv.ua) являє собою інформаційний ресурс для всіх, хто цікавиться проблемами освіти в регіоні, тенденціями розвитку освіти і науки в Україні та світі. Він містить такі розділи «Новини», «Департамент освіти і науки», «Відділи освіти», «Заклади обласного підпорядкування», «Середня, дошкільна та позашкільна освіта», «Простехосвіта», «Вища освіта», «Конкурси, олімпіади», «Проекти, програми, акції».

\section{III Результати}

Проведений аналіз дозволив з'ясувати, що в Українському сегменті Інтернет є інформаційні ресурси, які школи можуть застосовувати для оптимізації навчального процесу. Це портали, які класифіковано нами як сервісні: Класна оцінка - http://klasnaocinka.com.ua, Щоденник - shodennik.ua та ін. Проте ці сервіси не мають такий функціонал, як можливість здійснювати управління персоналом школи.

Після проведення аналізу наявних засобів для розробки внутрішнього порталу вчителя для оптимізації навчального процесу загальноосвітньої школи нами було обрано хмарний сервіс «Бітрікс24».

Після налаштування порталу адміністратором учителя можуть скористатися всіма його можливостями: писати повідомлення в живій стрічці; отримувати і ставити завдання; спілкуватися у чаті; працювати з календарем; створювати власний сайт; користуватися сховищем файлів та поштою тощо.

Бітрікс 24, як будь-яка інша система керування компанією, є веб-додатком, розташованим на сервері й доступ до нього здійснюється через браузер. Сервер зазвичай розташований в будівлі компанії (школі) або у провайдера. Бітрікс 24 написана на PHP з використанням SQL-бази даних (MySQL, InnoBD). Завдяки розвиненій модульній архітектурі, можливості Вitrix24 можуть легко розширюватися сторонніми розробниками.

Після вдалого входу на портал кожному учителю варто заповнити свій профіль. Для цього треба у форму (рис. 1) вести відповідні дані: контактний e-mail; e-mail для пошти; ім'я; прізвище; по батькові; фотографія; мобільний телефон; посада.

Як додаткову інформацію пропонується ввести такі дані: часовий пояс, WWW-сторінка, місто, стать, дата народження, skype, Twitter, Facebook, Linkedln, інші сайти, навички, інтереси.

Для того, щоб до профрілю додати фотограффію потрібно натиснути на кнопку [Додати фотограффію] і обрати потрібний файл. Для того, щоб наочно представити структуру школи, потрібно на головній сторінці перейти в розділ Співробітники. 
Після реєстрації директора школи, всіх учителів і співробітників вони автоматично відобразяться у структурі. Адміністратор порталу може розподілити їх на підрозділи, призначивши з переліку наявних співробітників відповідних людей (рис. 2).

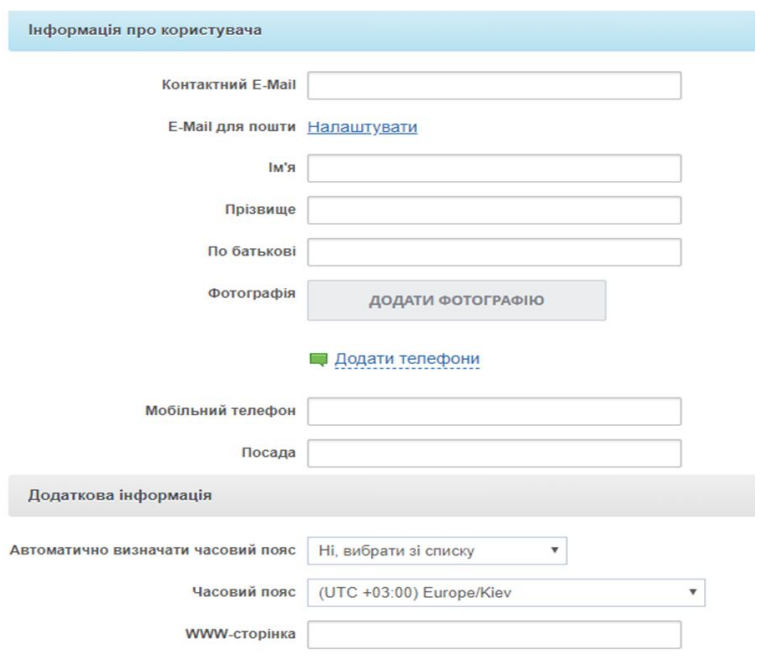

Рис. 1. Форма для заповнення профілю співробітника у «Бітрікс24»

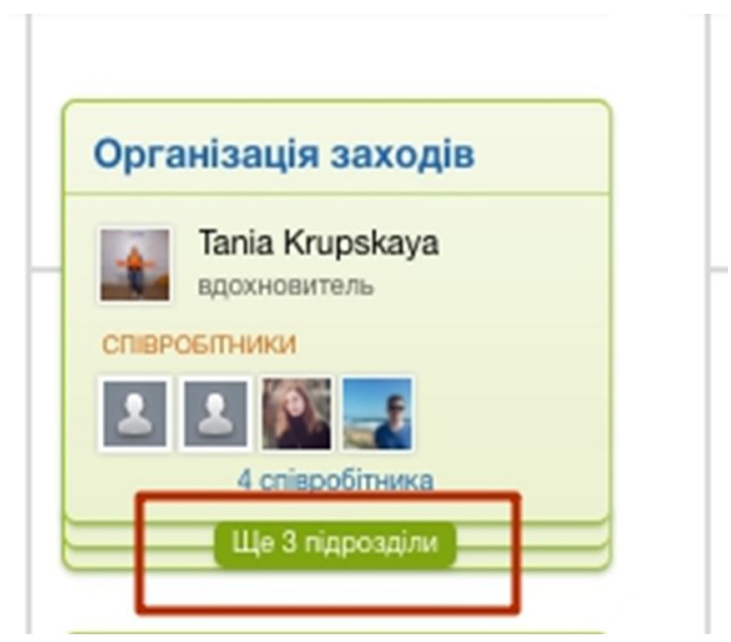

Рис. 2. Організація структури школи у «Бітрікс24»

На порталі для комунікації з колегами застосовується «Жива стрічка» та «Загальний чат».

Для того, що написати повідомлення у «Жива стрічка», потрібно перейти у розділ «Жива стрічка» та у відповідному полі написати повідомлення.

Співробітник може просто увести у поле текст або додати до нього файл, посилання, відео, цитату, згадку (ім'я співробітника), тег (для зручного пошуку) або записати відео, щоб потім його додати до повідомлення (рис. 3).

Повідомлення можна надіслати всім співробітникам (За замовчуванням), або додати конкретних співробітників, які отримають повідомлення. Це здійснюється у полі «Кому: Всі співробітники +Додати ще».

Одержувачі побачать повідомлення в загальній стрічці. Якщо адресували повідомлення комусь конкретно, одержувач отримає повідомлення у бізнес-чаті. Якщо повідомлення адресовано робочій групі, воно з'явиться додатково у стрічці цієї групи і всі учасники цієї групи легко знайдуть його.

Крім повідомлення у «Живу стрічку» можна додати Завдання (рис. 4). 


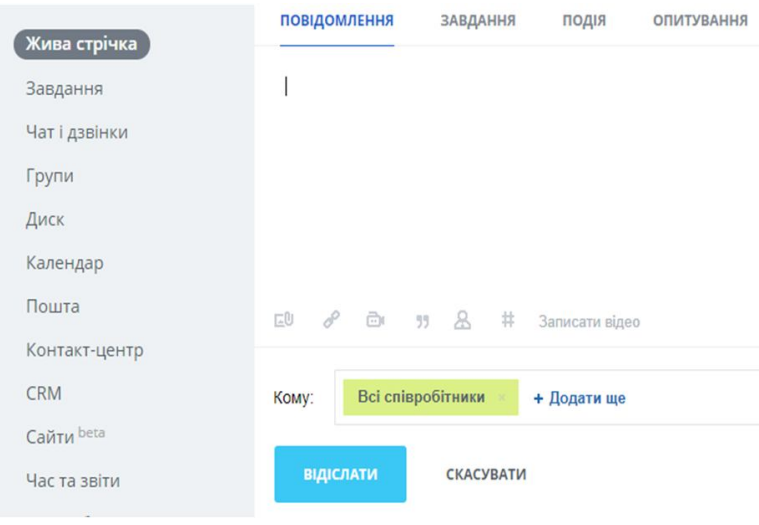

Рис. 3. Поле повідомлення у «Живій стрічці»

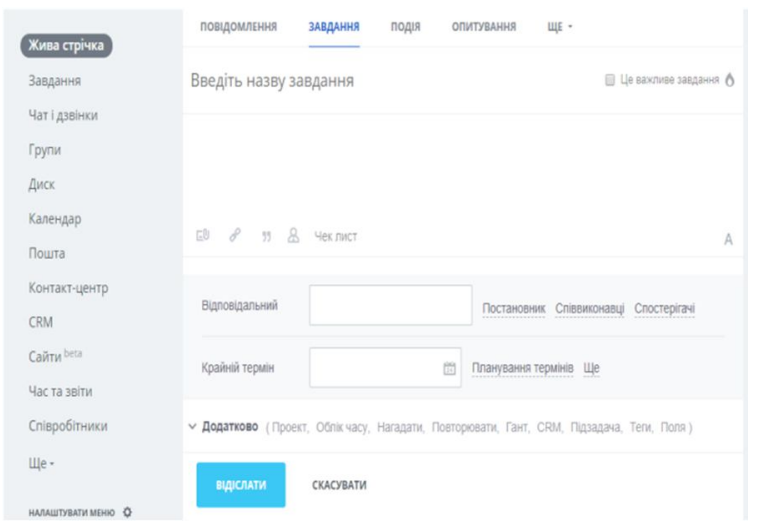

Рис. 4. Додавання Завдання у «Живу стрічку»

Для задач існують 4 ролі: Відповідальний, Постановник, Співвиконавець і Спостерігач:

1) Відповідальний - той, хто безпосередньо буде виконувати завдання.

2) Постановник - співробітник, який призначив завдання. Саме постановнику потрібно буде підтверджувати його виконання.

3) Співвиконавці - співробітники, які будуть допомагати виконувати завдання, якщо необхідно. Вони мають ті самі права в завданні, що і Відповідальний.

4) Спостерігачі - співробітники, які стежать за виконанням завдання, отримують сповіщення і можуть залишати коментарі, але напряму у виконанні не беруть участь.

Вкажіть назву і детальний опис завдання. У назві рекомендується вказувати коротко суть робіт так буде легше орієнтуватися в списку завдань, особливо якщо їх дуже багато. Чек-лист дозволяє створювати власний перелік дій, пункти якого можна відзначати як виконані. Його дуже зручно використовувати для фріксування етапів виконання будь-якого великого завдання. Підняти пріоритет завдання можна по кліку на опцію Це важливе завдання в правому верхньому куті форми. Так відповідальний співробітник зможе зрозуміти, що завдання потрібно виконати терміново. Важлива властивість завдання - це Крайній термін. Дедлайни можна визначати як за допомогою календаря, так і вручну. За допомогою посилання Планування термінів вказуються додаткові параметри щодо часу виконання завдання.

Для деяких завдань потрібно вказати особливі налаштування, щоб більш точно організувати їх виконання. Для цього треба натиснути на посилання «Додатково» та визначте додаткові опції створюваного завдання. Тут можна: прив'язати завдання до певного проекту, включити облік часу, встановити нагадування, додати відразу кілька нагадувань та обрати, кому нагадати про завдання: відповідальному, постановнику або собі. Повідомлення буде відправлено на електронну адресу співробітника або в як особисте повідомлення. Опція Повторювати завдання дозволяє створити новий шаблон завдання. При створенні можна відразу вказати, що створюється підзавдання. До задачі можна прив'язати елементи CRM за допомогою відповідного поля. Завдання, прив'язане до елементу CRM, відобразиться в картці на закладці Справи та з'явиться на сторінці Мої справи відповідального за її 
виконання. Ще до завдання можна додати теги, які дозволять швидко знайти його, а також пов'язані або попередні завдання.

Жива стрічка являє собою сторінку, на якій виводяться останні події порталу: новини, коментарі, нові файли, системні події і т. д. У ній можна переглядати всі події, які до вас відносяться, за весь час життя порталу. Можна залишати коментарі до подій, ставити лайки, влаштовувати голосування, сповіщати ваших колег про важливі події та оголошення. Головне завдання «Живої стрічки» - створити живе спілкування в режимі реального часу і спростити взаємодію в компанії.

У «Живій стрічці» можна створити подію для календаря (рис. 5). Для цього потрібно обрати вкладку «Подія» для повідомлення і ввести параметри: Назва події, Дата і час початку, Дата і час завершення, Нагадати про подію за, Місце проведення, Учасники. У розділі Додатково можна обрати параметри зайнятості співробітника, важливості та повторюваності події, а також певний календар для події (власник чи загальний).

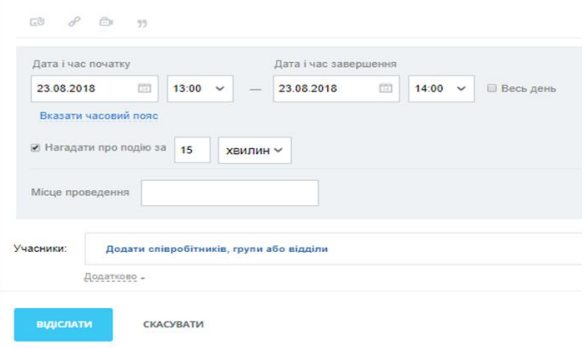

Рис. 5. Створення Події у «Живій стрічці»

Цікавою можливістю «Живої стрічки» на порталі є створення опитування. Для цього потрібно обрати вкладку «Опитування» у «Живій стрічці» та обрати параметри для нього:

1) текст запрошення до опитування у основному поля, де можна також додати файл, посилання, відео, цитату, згадку, тег;

2) Кому: обрати тих співробітників, які запрошуються до опитування ч всіх співробітників;

3) Питання: власне ввести текст питання для опитування;

4) Відповідь 1, Відповідь 2: ввести варіанти відповідей для опитування;

5) Додати питання: у разі потреби поставити не одне, а кілька запитань у опитуванні.

Крім переліченого на основних вкладках повідомлення «Живої стрічки» має можливість додавання файлів, подяки чи важливого повідомлення.

Для того, щоб висловити подяку з «Живої стрічки» виберіть вкладку «Подяка», вкажіть, кому ви хочете подякувати і виберіть відповідний значок під текстом повідомлення (рис. 6).

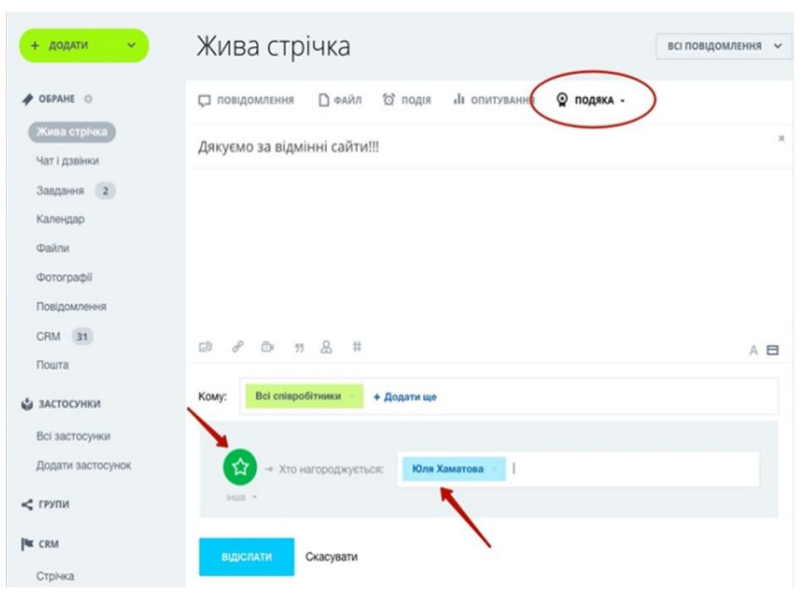

Рис. 6. Додавання подяки у «Живій стрічці» 
Для того, щоб додати важливе повідомлення, виберіть тип повідомлення «Важливе повідомлення», напишіть саме повідомлення та виберіть одержувачів. Після публікації цього повідомлення, з'явиться кнопка «Прочитано». Кожен співробітник після прочитання повинен їі натиснути. Так він показує, що ознайомився з інформацією. Поки співробітник не натисне кнопку, у нього буде відображатися повідомлення з правого боку сторінки.

Система фіксує кількість співробітників, які прочитали це повідомлення. Лічильник показує кількість співробітників, які ознайомилися з оголошенням, а прокрутивши список, можна побачити, хто саме це зробив.

Якщо учитель бажає не загубити важливу інформацію, то він може додати повідомлення з «Живої стрічки» в обране. Для цього слід натиснути на повідомленні «Ще» і обрати параметр «Додати в обране» або позначте повідомлення спеціальною іконкою у верхньому правому куті (зірочка).

Знайти всі обрані повідомлення можна, якщо вибрати в фільтрі «Обране» у «Живій стрічці» (рис. 7).

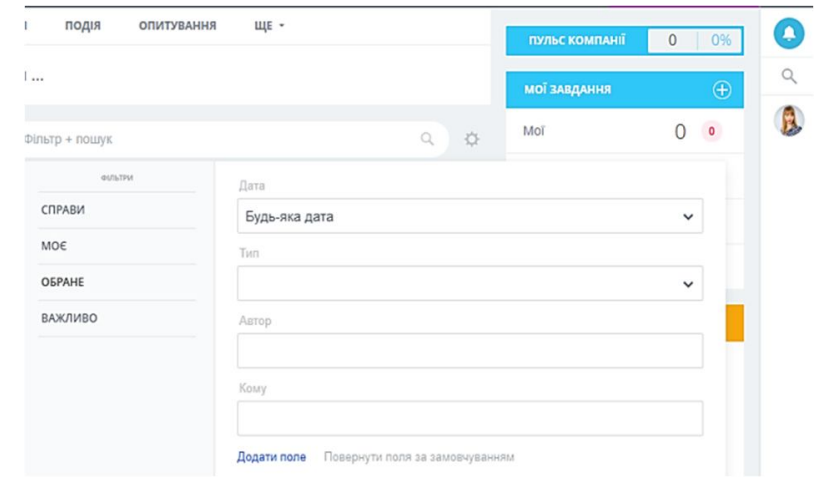

Рис. 7. Відображення обраних повідомлень у «Живій стрічці»

Другий розділ панелі порталу - Завдання. Як поставити завдання з «Живої стрічки» описано було вище. Воно не відрізняється віт того, що можна зробити у цьому розділі. Зупинимося докладніше на деяких аспектах Завдання.

У налаштуваннях завдання можна зустріти такий параметр як Гант. Він дозволяє додати до завдання діаграму Ганта. Це особливий вид роботи з завданнями прямо в календарній сітці. На ній відображається візуальне представлення тривалості та крайніх термінів за всіма завданнями. Щоб перейти до неї потрібно натиснути кнопці «Гант» в правому меню Налаштування завдань (рис. 8).

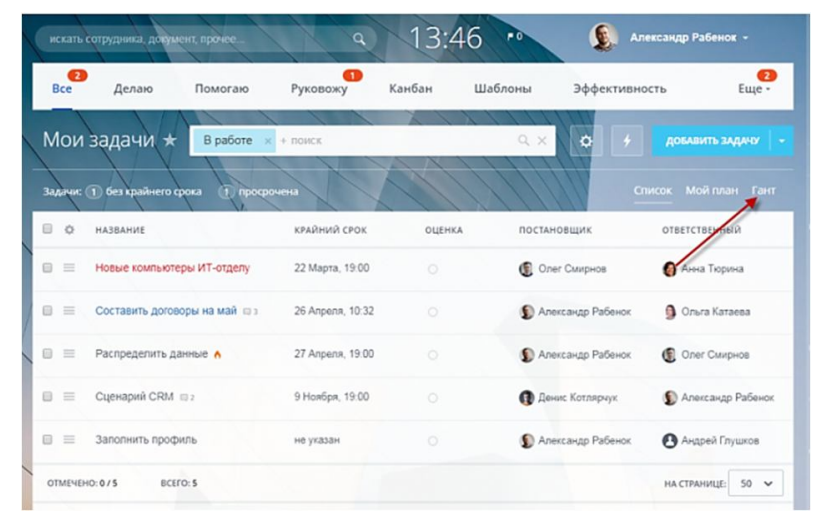

Рис. 8. Додавання Діаграми Ганта у Завдання

Кожне завдання являє собою блок, розташований у календарній сітці. Вид блоків визначають дата створення, старту, фінішу та крайній термін (рис. 9). 


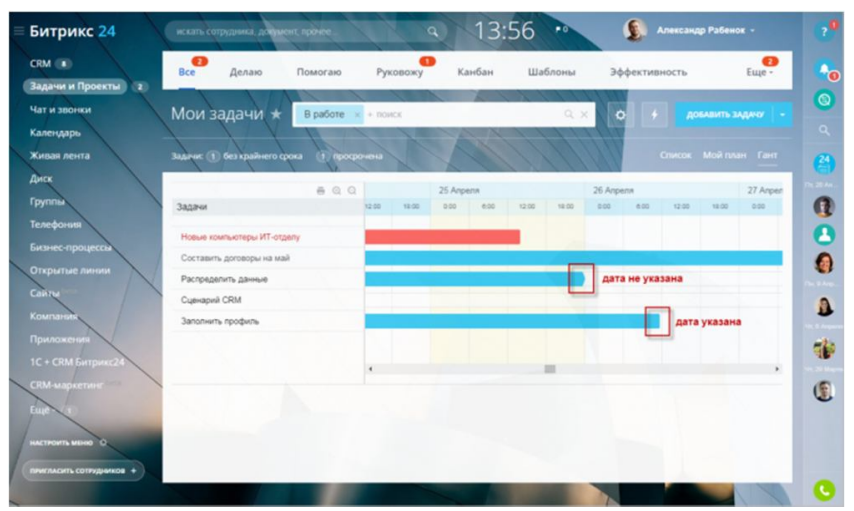

Рис. 9. Вигляд Діаграми Ганта

\section{1. Дата старту.}

Початок блоку - це дата старту завдання. Можна мишкою зрушувати дату старту на потрібний вам термін. При створенні або зміні завдання ця дата вказується в полі Почати завдання 3 (в Планування термінів). Якщо нічого не вказувати, датою старту буде Дата створення завдання.

2. Дата фінішу

Кінець блоку - це дата ймовірного завершення завдання. При створенні або зміні завдання ця дата вказується в полі Завершення. Ї̈̈ теж можна переносити мишкою. Зовнішній вигляд блоків буде відрізнятися, залежно від того, вказана ця дата чи ні.

3. Крайній термін

Якщо для завдання вказаний крайній термін, то в рядку з нею з'явиться червона смужка.

Якщо раптом так вийшло, що завдання прострочили, то після проходження дедлайну воно буде пофрарбовано в червоний колір. Постановник завдання може заборонити відповідальному зрушувати терміни виконання. Для цього потрібно при створенні або редагуванні зняти галочку з пункту Дозволити відповідальному міняти терміни завдання.

За замовчуванням при створенні завдання враховується робочий час. Якщо при перенесенні термінів завдання потрапляє на вихідний день, то терміни будуть перенесені на найближчий робочий час. Щоб відключити облік робочого часу, зніміть галочку з пункту Пропустити вихідні та святкові дні. Завдання з урахуванням робочого часу на діаграмі Ганта мають особливий вигляд. Темна смуга показує реальний час, коли співробітник запускав таймер і працював над завданням.

Отже, основні рекомендації по роботі порталу для оптимізації навчального процесу учителів дають можливість працювати з подібним засобом у загальноосвітній школі.

\section{IV Обговорення}

В останні роки подальшого динамічного розвитку набувають засоби і технології інформаційнокомунікаційних мереж, зокрема Інтернет, що утворюють комп'ютерно-технологічну платформу навчального середовища сучасної освіти. На цій основі здійснюється предметно-технологічна організація інформаційного освітнього простору, упорядковуються процеси накопичення і зберігання різних предметних колекцій електронних освітніх ресурсів, забезпечується рівний доступ до них тих, хто навчається, суттєво покращується інформаційно-комунікативна підтримка процесів навчання, вимірювання та моніторингу рівня навчальних досягнень учнів, проведення наукових досліджень та управління освітою [29].

Однією з умов рефрормування шкільної освіти є розробка і упровадження сучасних технологій навчання школярів і технологій управління навчально-виховним процесом. Нові комп'ютерні технології значною мірою розширюють діапазон освітніх можливостей, які здатні корінним чином змінити не тільки організацію навчального процесу, але і систему освіти в цілому.

Розроблений нами внутрішній портал вчителя - система управління внутрішнім інформаційним ресурсом загальноосвітнього навчального закладу для колективної роботи над завданнями, проектами і документами, для ефективних внутрішніх комунікацій. Його використання дозволяє швидко і легко спілкуватися з колегами, вирішуючи робочі питання, працюючи разом над завданнями і проектами; 
допомагає керівникам контролювати виконання завдань; спілкуватися з колегами, обмінюватися інформацією та отримувати миттєву реакцію на повідомлення, не витираючи кошти на мобільні дзвінки та часу на біганину по кабінетах. Тут є можливість безкоштовно скористатися усіма перевагами Google Docs i Microsoft Office Online для керування документами, спільно працювати над ними, створювати і розповсюджувати шкільну документацію. Календарі дозволяють планувати класні години, зустрічі 3 батьками та педагогічні наради, вибирати зручний час для всіх учасників, підключати свої календарі до мобільного телефонну або планшету (iPhone, iPad, Android). Система обліку робочого часу підвищує дисципліну, дозволяє відзначати початок і кінець робочого дня, перерви, відсутності, швидко планувати зустрічі в календарях і завдання на день. На основі цих даних формується звіт за робочим часом кожного вчителя. У звіт автоматично включаються всі звіти за день і виконані завдання за певний період. Крім цього можна враховувати витрати часу на виконання завдань. Звіти можна налаштувати: щодня, щотижня, щомісяця. Портал дозволяє зробити структуру загальноосвітнього навчального закладу прозорою для керівників і співробітників, а також використовувати інструменти мотивації.

\section{V Висновки}

Отже, досягнення найвищої ефективності навчального процесу загальноосвітнього навчального закладу на сьогодні неможливо без упровадження в навчальний процес новітніх прогресивних інформаційних технологій. Запровадження цих технологій $є$ актуальним і перспективним, оскільки вони дозволяють забезпечити підвищення рівня ефективності та прийняття оптимальних управлінських рішень, використання необхідних інформаційних ресурсів. Головним пріоритетом оновлення змісту, форм та методів навчання і виховання в закладах освіти $€$ формування інформаційних ресурсів загальноосвітніх навчальних закладів.

У ході дослідження було узагальнено поняття освітнього порталу як системного багаторівневого об'єднання різних інформаційно-освітніх ресурсів та програмних комплексів, що працюють на основі єдиної бази даних і єдиних стандартів обміну інформацією, розраховане на певну аудиторію користувачів і призначене для аналізу, обробки, доставки освітньої інформації та надання доступу до різних сервісів на основі персоналізації за допомогою будь-якого пристрою, підключеного до Інтернет.

Розроблений нами внутрішній портал вчителя являє собою нову компоненту системи освіти, орієнтовану на інформаційне обслуговування навчально-освітньої діяльності, що здатний в інтерактивному режимі охопити широке коло користувачів і створити необхідні умови для оперативного розповсюдження інформації. Використання внутрішнього порталу дає можливість досліджувати та виконувати якісно-змістові перетворення на основі сучасних педагогічних технологій, обробляти й аналізувати інформацію, визначати шляхи вирішення педагогічних проблем, а також забезпечує на сучасному технологічному рівні ефективну інформаційну підтримку освітньої діяльності, інтерактивне спілкування користувачів порталу між собою з метою ефективної реалізації навчально-освітніх заходів.

\section{Бібліографрічні посилання}

[1] Вембер В.П. Інформатизація освіти та проблеми впровадження педагогічних програмних засобів в навчальний процес / Інформаційні технології і засоби навчання, 2007. Том 3. №2 URL: https://journal.iitta.gov.ua/index.php/itt/article/view/262 (дата звернення: 20.01.2019).

[2] Гончарова О.М. Інформатизація освіти як пріоритетний напрямок модернізації освіти в умовах інфрормаційного суспільства / Проблеми сучасної педагогічної освіти. Ялта: РВВ КДГІ, 2005. Вип.7. Ч.1. С. 59-64.

[3] Кремень В.Г. Інформатизація освіти - провідний напрям підвищення результативності навчального процесу / Комп' ютер у школі та сім' ї, 2011. Вип. 1. С. 3-6.

[4] Осадчий В.В. Педагогічні засади професійного консультування молоді засобами Інтернет [Текст]: дис. ... канд. пед. наук: 13.00.04; Інститут педагогіки і психології професійної освіти АПН України. К., 2005. 213 с.

[5] Рамський Ю.С. Інформаційне суспільство. Інформатизація освіти / Комп'ютерно-орієнтовані системи навчання: зб. наук. праць. К.: НПУ ім. МП Драгоманова, 2003. Вип. 7. С. 16-28.

[6] Биков В.Ю. Хмарна комп'ютерно-технологічна платформа відкритої освіти та відповідний розвиток організаційнотехнологічної будови IT-підрозділів навчальних закладів / Теорія і практика управління соціальними системами: філософрія, психологія, педагогіка, соціологія. Харків: НТУ "ХПІ", 2013. № 1. С. 81-98.

[7] Ільїна Ю.Н. Інформатизація освіти: дистанційне розвиваюче середовище. Суб'єкт - суб'єктна взаємодія / Матеріали IX Міжнародної наукової конференції «Традиція і культура. Феномен діалогу: традиція і сучасність». К., 2010. Ч. 4. С. 33-34. 
[8] Козяр М.М. Модернізація навчально-виховного процесу на основі використання єдиного інфрормаційного освітнього середовища / Теорія і практика управління соціальними системами: філософія, психологія, педагогіка, соціологія. Харків: НТУ "ХПІ", 2011. № 1. С. 3-8.

[9] Забродська Л.М. Інформатизація управління навчально-виховним процесом у загальноосвітньому навчальному закладі [Текст]: дис. ... канд. пед. наук.: 13.00.01 Ін-т педагогіки АПН України. К., 2002. 210 с.

[10] Вакалюк Т.А., Шевельова М.К. Використання інформаційно-комунікаційних технологій в загальноосвітніх школах для підвищення якості освіти / Інформаційно-комунікаційні технології як засіб підвищення якості освіти: збірник наук. та науково-метод. праць. Хмельницький: Видавництво ХОІППО, 2015. С. 40-45.

[11] Вербовський І. Інформатизація управління навчальним закладом як один зі шляхів підвищення ефективності освітньої діяльності / Науковий вісник Мелітопольського державного педагогічного університету. Серія: Педагогіка, 2015. № 1. С. 317-321.

[12] Коврижкін О.Г. Проблема інформатизації адміністративних процесів в навчальних закладах / Комп'ютерноорієнтовані системи навчання. К: НПУ ім. М.П. Драгоманова, 2001. Вип. 4. С. 139-143.

[13] Козлакова Г.О. Комп'ютеризовані технології обробки ділової інформації: навч. посіб. Київ-Рівне: РдтУ, 2001. 233 с.

[14] Гевал П.А. Управлінська діяльність комплексу в умовах інформатизації навчально-виховного процесу / Комп'ютерноорієнтовані системи навчання. К.: НПУ ім. М.П. Драгоманова, 2001. Вип. 4. С. 205-209.7

[15] Коваль О.М. Соціально-педагогічні можливості нових інформаційних технологій / Матеріали Всеукр. науковопрактичної конф. «Сучасні педагогічні інновації у підготовці і післядипломній освіті педагогічних працівників». Черкаси: ТОВ "ОКО-ПЛЮС", 2000. С. 85-88.

[16] Сисоєва С.О., Осадчий В.В. Професійне консультування молоді засобами Інтернет-порталу Професійна освіта: педагогіка і психологія / Польсько-Український та Українсько-польський щорічник. Ченстохова-Київ: Академія ім. Яна Длугоша, 2006 Вип.VIII. C.185-193.

[17] Бабинский А.З., Букатов А.А., Шапиро В.А., Шаройко О.В. Определение базовых сервисов, разработка методики наполнения и методов реализации образовательных порталов. URL: http://ict.edu.ru/ft/001676//Bukatov.pdf (дата звернення: 31.01.2019).

[18] Триус Ю.В., Бесєдков С.В., Пустовіт В.А. Освітньо-науковий портал як прототип цифрового університету / Вісник Харківського національного університету. Серія: Математичне моделювання. Інформаційні технології. Автоматизовані системи управління. 2004. Вип. 3. С. 100-114.

[19] Оринштейн Д. Корпоративные порталы / ComputerWORLD, 1999. № 41. С. 34.

[20] Соловйов В.М., Сердюк О.А., Триус Ю.В. Організаційні особливості створення регіонального освітнього порталу / Теорія та методика навчання фундаментальних дисциплін у вищій технічній школі. Кривий Ріг: Видавничий відділ НМетАУ, 2003. С. 225-234.

[21] Береговой В.И., Иванников А.Д., Тихонов A.Н. Стратегия создания и развития сети образовательных порталов. URL: http://edu.ru/files/books/portals-2003/Ivannikov.pdf (дата звернення: 22.01.2019).

[22] Англо-український тлумачний словник з обчислювальної техніки, Інтернету і програмування. Вид. 2. К.: Видавничий дім «СофтПрес», 2006. 824 с.

[23] Солдаткин В.И. Образовательный портал: понятие и проблема регулирования / Телематика-2001: Тр. междунар. научн.-методич. конф. СПб.: СПбГИТМО, 2001. С. 205-206.

[24] Дрючатый Г.Ф., Заварихин А.Е., Красильникова В.А. Один из подходов к созданию образовательного портала / Сборник материалов международной конференции «Единая образовательная информационная среда: проблемы и пути развития». Томск, 2002. URL: https://ido.tsu.ru/other_res/pdf/4(8)Dryuchatyi_Zavarihin_Krasilnikova_(OrGU).pdf (дата звернення: 27.01.2019)

[25] Andreeva A.V., Mazhar E.N., Maximova N.A. Some Aspects of Implementation of Information Technologies in the Teaching Process / Middle-East Journal of Scientifi c Research, 2014. № 19 (1). pp. 19-23.

[26] Комаревцев Е.М. Образовательные порталы как средство систематизации и структурирования инсрормации [Текст]: дис. на соиск. учен. степ. канд. пед. наук. Ставрополь, 2004. 207 с.

[27] Напалкова И.Г. Использование образовательных порталов при подготовке студентов в вузе / Вестник Мордовского университета, 2009. №2. С. 344-349.

[28] Educational Era. URL: https://www.ed-era.com (дата звернення: 04.02.2019).

[29] Кремень В.Г., Биков В.Ю. Інноваційні завдання сучасного етапу інформатизації освіти / Сучасні інформаційні технології та інноваційні методики у підготовці фахівців: методологія, теорія, досвід, проблеми: зб. наук. праць. КиївВінниця: ТОВ фрірма "Планер", 2014. Вип. 37. С. 3-15.

\section{References}

[1] Vember, V.P. (2007), Informatyzatsiia osvity ta problemy vprovadzhennia pedahohichnykh prohramnykh zasobiv v navchalnyi protses. available / Informatsiini tekhnolohii i zasoby navchannia, Vol. 3. №2. at: https://journal.iitta.gov.ua/index.php/ittl/article/view/262 (accessed January 20, 2019). [in Ukrainian]

[2] Goncharova, O.M. (2005), Informatyzatsiia osvity yak priorytetnyi napriamok modernizatsii osvity v umovakh informatsiinoho suspilstva / Problemy suchasnoi pedahohichnoi osvity, Yalta, Iss. 7, Part 1, npp. 59-64. [in Ukrainian]

[3] Kremen, V.G. (2011), Informatyzatsiia osvity - providnyi napriam pidvyshchennia rezultatyvnosti navchalnoho protsesu / Komp' yuter u shkoli ta sim' yi, Iss. 1. npp. 3-6. [in Ukrainian] 
[4] Osadchiy, V.V. (2005), Pedahohichni zasady profesiinoho konsultuvannia molodi zasobamy Internet [Pedagogical bases of professional consulting of young people by Internet facilities] (Dys. kand. ped. nauk), Institute of pedagogy and psychology of vocational education Academy of Pedagogical Sciences of Ukraine, Kyiv. [in Ukrainian]

[5] Ramsky, Yu.S. (2003), Informatsiine suspilstvo. Informatyzatsiia osvity / Kompiuterno-oriientovani systemy navchannia, NPU after M.P. Drahomanov, Kyiv, Iss. 7, npp. 16-28. [in Ukrainian]

[6] Bykov, V.lu. (2013), Khmarna kompiuterno-tekhnolohichna platforma vidkrytoi osvity ta vidpovidnyi rozvytok orhanizatsiinotekhnolohichnoi budovy IT-pidrozdiliv navchalnykh zakladiv / Teoriia i praktyka upravlinnia sotsialnymy systemamy: filosofiia, psykholohiia, pedahohika, sotsiolohiia, Kharkiv, NTU "KhPI", № 1, npp. 81-98. [in Ukrainian]

[7] Ilina, Yu.N. (2010), Informatyzatsiia osvity: dystantsiine rozvyvaiuche seredovyshche. Subiekt - subiektna vzaiemodiia / Materialy IX Mizhnarodnoi naukovoi konferentsii «Tradytsiia i kultura. Fenomen dialohu: tradytsiia i suchasnist», Kyiv, Part 4, npp 33-34. [in Ukrainian]

[8] Koziar, M.M. (2011), Modernizatsiia navchalno-vykhovnoho protsesu na osnovi vykorystannia yedynoho informatsiinoho osvitnoho seredovyshcha / Teoriia i praktyka upravlinnia sotsialnymy systemamy: filosofiia, psykholohiia, pedahohika, sotsiolohiia, Kharkiv, NTU "KhPI", № 1, npp. 3-8. [in Ukrainian]

[9] Zabrodska, L.M. (2002), Informatyzatsiia upravlinnia navchalno-vykhovnym protsesom u zahalnoosvitnomu navchalnomu zakladi [Informatization of the management of the educational process in a general educational institution] (Dys. kand. ped. nauk), Institute of pedagogy Academy of Pedagogical Sciences of Ukraine, Kyiv. [in Ukrainian]

[10] Vakaliuk, T.A. (2015), Vykorystannia informatsiino-komunikatsiinykh tekhnolohii v zahalnoosvitnikh shkolakh dlia pidvyshchennia yakosti osvity / Informatsiino-komunikatsiini tekhnolohii yak zasib pidvyshchennia yakosti osvity, Khmelnytskyi, Publishing House of Khmelnytsky Regional Institute of Postgraduate Pedagogical Education, npp. 40-45. [in Ukrainian]

[11] Verbovskyi, I. (2015), Informatyzatsiia upravlinnia navchalnym zakladom yak odyn zi shliakhiv pidvyshchennia efektyvnosti osvitnoi diialnosti / Scientific herald of Melitopol State Pedagogical University. Series: Pedagogy, № 1, npp. 317-321. [in Ukrainian]

[12] Kovryzhkin, O.G. (2001), Problema informatyzatsii administratyvnykh protsesiv v navchalnykh zakladakh / Kompiuternooriientovani systemy navchannia, NPU after M.P. Drahomanov, Kyiv, Iss. 4, npp. 139-143. [in Ukrainian]

[13] Kozlakova, H.O. (2001), Kompiuteryzovani tekhnolohii obrobky dilovoi informatsii, Kyiv-Rivne, 233 p. [in Ukrainian]

[14] Geval, P.A. (2001), Upravlinska diialnist kompleksu v umovakh informatyzatsii navchalno-vykhovnoho protsesu I Kompiuterno-oriientovani systemy navchannia, NPU after M.P. Drahomanov, Kyiv, Iss. 4, npp. 205-209. [in Ukrainian]

[15] Koval, O.M. (2000), Sotsialno-pedahohichni mozhlyvosti novykh informatsiinykh tekhnolohii / Materialy Vseukr. naukovopraktychnoi konf. "Suchasni pedahohichni innovatsii u pidhotovtsi i pisliadyplomnii osviti pedahohichnykh pratsivnykiv», Cherkasy, TOV "OKO-PLIUS", npp. 85-88. [in Ukrainian]

[16] Sysoieva, S.O. (2006), Profesiine konsultuvannia molodi zasobamy Internet-portalu Profesiina osvita: pedahohika i psykholohiia / Polsko-Ukrainskyi ta Ukrainsko-polskyi shchorichnyk. Chenstokhova-Kyiv, Yana Dlugosh Academy, Iss. VIII, npp. 185-193. [in Ukrainian]

[17] Babinsky, A.Z. (2003), Opredelenie bazovyih servisov, razrabotka metodiki napolneniya i metodov realizatsii obrazovatelnyih portalov, available at: http://ict.edu.ru/ft/001676//Bukatov.pdf (accessed January 31, 2019). [in Russian]

[18] Tryus, Yu.V. (2004), Osvitno-naukovyi portal yak prototyp tsyfrovoho universytetu / Bulletin of the Kharkiv National University. Series: Mathematical Modeling. Information Technologies. Automated Control Systems, Iss. 3, pp. 100-114. [in Ukrainian]

[19] Orinshteyn, D. (1999), Korporativnyie portalyi / ComputerWORLD, № 41, p. 34. [in Russian]

[20] Solovyov, V.M. (2003), Orhanizatsiini osoblyvosti stvorennia rehionalnoho osvitnoho portalu / Teoriia ta metodyka navchannia fundamentalnykh dystsyplin u vyshchii tekhnichnii shkoli, Kryvyi Rih, Vydavnychyi viddil NMetAU, npp. 225-234. [in Ukrainian]

[21] Beregovoy, V.I. (2003), Strategiya sozdaniya i razvitiya seti obrazovatelnyih portalov, available at: http://edu.ru/files/books/portals-2003/Ivannikov.pdf (accessed January 22, 2019). [in Russian]

[22] Anhlo-ukrainskyi tlumachnyi slovnyk z obchysliuvalnoi tekhniky, Internetu i prohramuvannia (2005), Kyiv, Vydavnychyi dim «SoftPres». 824 p. [in Ukrainian]

[23] Soldatkin, V.I. (2001), Obrazovatelnyiy portal: ponyatie i problema regulirovaniya / Telematika-2001: Tr. mezhdunar. nauchn.-metodich. konf., Saint Petersburg, npp. 205-206. [in Russian]

[24] Driuchatyi, G.F. (2002), Odin iz podhodov k sozdaniyu obrazovatelnogo portala / Sbornik materialov mezhdunarodnoy konferentsii «Edinaya obrazovatelnaya informatsionnaya sreda: problemyi i puti razvitiya», Tomsk, available at: https://ido.tsu.ru/other_res/pdf/4(8) Dryuchatyi_Zavarihin_Krasilnikova_(OrGU).pdf (accessed January 27, 2019). [in Russian]

[25] Andreeva, A.V. (2014), Some Aspects of Implementation of Information Technologies in the Teaching Process // Middle-East Journal of Scientifi c Research. № 19 (1). npp. 19-23. [in English]

[26] Komarevtsev, E.M. (2004), Obrazovatelnyie portalyi kak sredstvo sistematizatsii i strukturirovaniya informatsii [Educational portals as a means of systematization and structuring of information] (Dys. kand. ped. nauk), Stavropol. [in Russian]

[27] Napalkova, I.G. (2009), Ispolzovanie obrazovatelnyih portalov pri podgotovke studentov v vuze / Bulletin of Mordovia University, Saransk, №2, npp. 344-349. [in Russian]

[28] Educational Era, available at: https://www.ed-era.com (accessed February 04, 2019). [in Ukrainian] 
[29] Kremen, V.H. (2014), Innovatsiini zavdannia suchasnoho etapu informatyzatsii osvity / Suchasni informatsiini tekhnolohii ta innovatsiini metodyky u pidhotovtsi fakhivtsiv: metodolohiia, teoriia, dosvid, problemy, Kyiv-Vinnytsia, TOV firma "Planer", Iss. 37, npp. 3-15. [in Ukrainian]

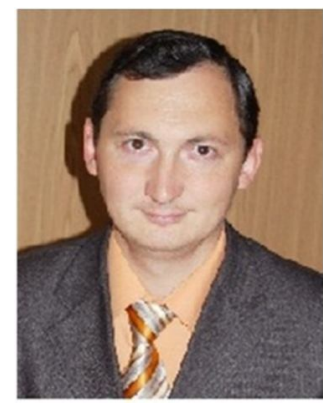

Осадчий Вячеслав Володимирович.

Д.пед.н., професор, профресор кафеедри інфоорматики і кібернетики,

Мелітопольський державний педагогічний університет імені Богдана Хмельницького,

вул. Гетьманська, 20, м. Мелітополь Запорізька обл., Україна, 72312.

Тел. (0619) 44-04-64. E-mail: osadchyi@mdpu.org.ua

\section{Osadchyi Viacheslav Volodymyrovych.}

Doctor of Pedagogical Science, Professor, Professor of the Department of Informatics and Cybernetics,

Bogdan Khmelnitsky Melitopol State Pedagogical University,

Str. Getmanska, 20, Melitopol, Zaporozhye region, Ukraine, 72312.

Tel. (0619) 44-04-64. E-mail: osadchyi@mdpu.org.ua

ORCID: https://orcid.org/0000-0001-5659-4774

Researcher ID: http://www.researcherid.com/rid//-8586-2016

Scopus ID: 57190217440

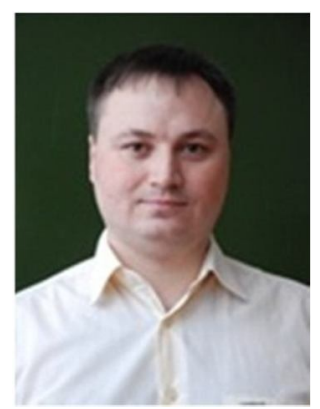

\section{Круглик Владислав Сергійович.}

Д.пед.н., доцент, профресор кафедри інформатики і кібернетики,

Мелітопольський державний педагогічний університет імені Богдана Хмельницького,

вул. Гетьманська, 20, м. Мелітополь Запорізької обл., Україна, 72300.

Тел. +38(095) 257 9204. E-mail: kryglikvlad@gmail.com

\section{Kruhlyk Vladyslav Serhiiovych.}

D.Sc. (Ed.), Associate Professor, Professor of Department of Informatics and Cybernetics,

Bogdan Khmelnitsky Melitopol State Pedagogical University,

Str. Hetmanska, 20, Melitopol, Zaporizhzhia region, Ukraine, 72312.

Tel. +38(095) 257 9204. E-mail: kryglikvlad@gmail.com

ORCID: https://orcid.org/0000-0002-5196-7241

Researcher ID: http://www.researcherid.com/rid/V-3861-2017

Scopus ID: https://www.scopus.com/authid/detail. uri?authorld=56006715100

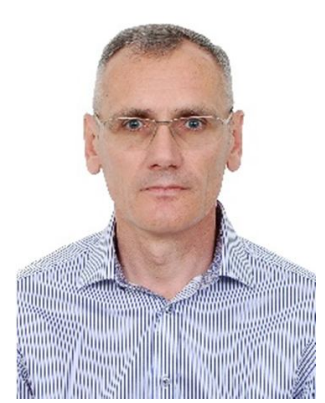

Прокоф'єв Євген Геннадійович.

К.пед.н., старший викладач кафедри інформатики і кібернетики,

Мелітопольський державний педагогічний університет імені Богдана Хмельницького,

вул. Гетьманська, 20, м. Мелітополь Запорізької обл., Україна, 72300.

Тел. +38(098) 494 9451. E-mail: e.prokofiev@bigmir.net

\section{Prokofiev levgen Hennadiiovych.}

Candidate of Pedagogical Sciences, Senior Lecturer of Department of Informatics and Cybernetics,

Bogdan Khmelnitsky Melitopol State Pedagogical University,

Str. Getmanska, 20, Melitopol, Zaporozhye region, Ukraine, 72312.

Tel. +38(098) 494 9451. E-mail: e.prokofiev@bigmir.net

ORCID: https://orcid.org/0000-0001-6524-1663

Researcher ID: http://www.researcherid.com/rid/C-5495-2019

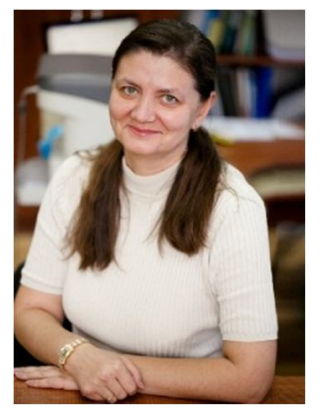

Сердюк Ірина Миколаївна.

Асистент кафедри інформатики і кібернетики,

Мелітопольський державний педагогічний університет імені Богдана Хмельницького,

вул. Гетьманська, 20, м. Мелітополь Запорізької обл., Україна, 72300.

Тел. +38(097) 718 2371. E-mail: serdiuk_iryna@mdpu.org.ua

\section{Serdiuk Iryna Mikolaevna.}

Assistant of Department of Informatics and Cybernetics,

Bogdan Khmelnitsky Melitopol State Pedagogical University,

Str. Getmanska, 20, Melitopol, Zaporozhye region, Ukraine, 72312.

Tel. +38(097) 718 2371. E-mail: serdiuk_iryna@mdpu.org.ua

ORCID: https://orcid.org/0000-0001-6808-0586

Researcher ID: http://www.researcherid.com/rid/A-5738-2018 


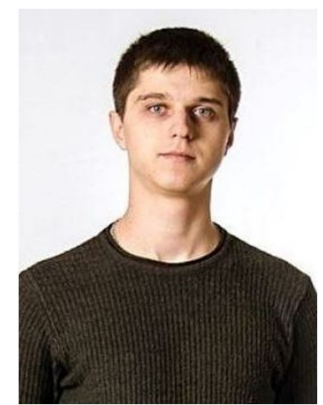

Купчак Євген Олександрович.

Студент аспірантури,

Мелітопольський державний педагогічний університет імені Богдана Хмельницького,

вул. Гетьманська, 20, м. Мелітополь Запорізької обл., Україна, 72312.

Тел. (0619) 44-04-64. E-mail: e.kupchak.it@gmail.com

\section{Kupchak Yevgen Oleksandrovych.}

PhD student,

Bogdan Khmelnitsky Melitopol State Pedagogical University,

Str. Getmanska, 20, Melitopol, Zaporozhye region, Ukraine, 72312.

Tel. (0619) 44-04-64. E-mail: e.kupchak.it@gmail.com

ORCID: https://orcid.org/0000-0003-3048-0853

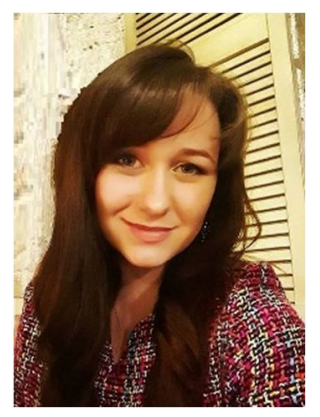

\section{Бурцева Євгенія Олександрівна.}

Студентка магістратури,

Мелітопольський державний педагогічний університет імені Богдана Хмельницького,

вул. Гетьманська, 20, м. Мелітополь Запорізька обл., Україна, 72312.

Тел. (0619) 44-04-64. E-mail: yevgeniya_burceva@mdpu.org.ua

\section{Burceva Yevgeniya Oleksandrivna.}

Student of Master Degree,

Bogdan Khmelnitsky Melitopol State Pedagogical University,

Str. Getmanska, 20, Melitopol, Zaporozhye region, Ukraine, 72312.

Tel. (0619) 44-04-64. E-mail: yevgeniya_burceva@mdpu.org.ua

ORCID: https://orcid.org/0000-0002-8527-9172

\section{Citation (APA):}

Osadchyi, V., Kruglik, V., Prokofiev, I., Serdiuk, I., Kupchak, Y., Burceva, Y. (2019). Internal teacher portal as a tool for optimization of the educational process of the general school. Engineering and Educational Technologies, 7 (1), 89-108. doi:

https://doi.org/10.30929/2307-9770.2019.07.01.09

\section{Цитування (ДСТУ 8302:2015):}

Осадчий В. В., Круглик В. С., Прокоф'єв Є. Г., Сердюк І. М., Купчак Є. О., Бурцева Є. О. Внутрішній портал вчителя як засіб оптимізації навчального процесу загальноосвітньої школи / Інженерні та освітні технології. 2019. Т. 7. № 1. С. 89-108. doi: https://doi.org/10.30929/2307-9770.2019.07.01.09

Обсяг статmі: $\quad$ сторінок-20 ; умовних друк. аркушів - 2,299 